Małgorzata Zachara

Institute of American Studies and Polish Diaspora Jagiellonian University, Krakow, Poland

\title{
Techno-Transatlantic \\ Science and Technology in Relations between the United States and Europe ${ }^{1}$
}

\begin{abstract}
The article focuses both on account technology as a factor in the twentieth-century relations of the United States and Europe and a view of transatlantic history through the lens of technology. It describes the trajectory of modernization through technology in certain characteristically transatlantic contexts - including the Cold War role, the advancement in military technologies and the international political competition. It demonstrates that technology development in many ways, provides structure for transatlantic cooperation and acting as a force reshaping political relations.
\end{abstract}

Key words: transatlantic cooperation, the United States, Europe, technology transfer, innovation, military technology

\section{Introduction}

Since the early $20^{\text {th }}$ century the Atlantic World has been a synonym for the most developed, politically influential and the richest part of the globe. The United States and the European Union represent the largest economic relationship in the world, accounting for nearly 30 percent of global merchandise trade, about 40 percent of world trade in services, and nearly half of the global GDP ${ }^{2}$ (Foreign Direct Investments...). Economies on both continents have been built on knowledge, technological advancement and the superiority of innovations. The US and the EU account for $63 \%$ of the top R\&D companies, $58 \%$ of all global R\&D and 18 of the top 20 knowledge regions (BILAT USA 2.0...).

1 This article was prepared as part of the: "Polska w stosunkach transatlantyckich narzędzia, perspektywy i znaczenie Polski w kształtowaniu debaty transatlantyckiej," research project funded by the National Science Centre in Poland. SYMFONIA: Interdisciplinary grant, UMO-2011/03/D/HS5/01116.

2 Europe is the largest regional investor in the United States. It accounted for nearly 70 percent of all foreign investment through 2014. These results include the 28 European Union (EU) countries and other European nations with an investment stake in the United States. 
Despite varying and frequent economic and political turbulence, the US and Europe remain each other's most important markets. No other commercial artery in the world is as well established, enjoying the benefits of integration and a long tradition of economic cooperation.

Technological advancements represent an important part of these relations that shape policies and practices in the transatlantic framework. The aim of this article is look at the technological aspect of the relations between the two traditionally most influential parts of the world, using science and technology (S\&T) as a tool of Western influence. The Unites States and Europe seem to lose this competitive advantage as China reclaims its place as one of the world's preeminent economies shifting from a low- and middle-tech manufacturing system to a sophisticated high-tech one. China already challenges the European Union in terms of expenditure on research and development as a share of its GDP, and produces about the same number of scientific publications, and more PhDs in natural sciences and engineering, than the United States (Veugelers). The rise of China on the global knowledge market has provoked deep concern about the sustainability of the American capacity for innovation, especially in light of the recent trend in the US to move to a more restrictive immigration policy. These transformations create a part of the departure for diagnosis of a transatlantic innovations strategy. The global competition framework is used as a ground for summarizing the previous stages of the transatlantic technological cooperation and diagnosis of its current status. Attention is mostly focused on:

- How technology and science have contributed to the development of the western nations and have established the conditions for a global model of prosperity?

- How issues connected to technology influence the condition of the transatlantic relationship, especially in the context of NATO cooperation?

- How would the possible loss of global technological superiority affect the economies and defense industrial base of the Western partners?

- Is technology cooperation a missed opportunity in building transatlantic relations?

What kind of a collaborative approach is possible for the United States and the European Union in the competitive international system?

World societies are strongly influenced by technology and mass entertainments provided by the transatlantic partners, and this sphere of social and economic activity represents one of the important features of their common relations. The issue of technology has been however, as joining as dividing both regions over the course of history, helping to define identities, build common self-perception but also intensifying rivalry. On the one hand, both allies consider technological advancement to be crucial for their vital national interests, as their economies and military systems heavily relied on innovation. On the other, in spite of their traditional bonds, they do not seem to recognize and realize all the potential created by their global technological preeminence and long cooperation. Political influence and aspirations also provide an interesting layer of analysis within this context. Since the beginning of the $20^{\text {th }}$ century, technological advancement has been an aspect of political position, a tool for building political power and securing the dominance in the international arena. Motivations for developing cutting edge military technologies - the atomic bomb being the most illuminating case - has been strictly political. Later on, primacy 
on computing, and in the manufacturing of computers, was treated as an important factor in the race for global leadership. Today, research on energy sources or the Internet of Things play the same role, being a tool in shaping relations and negotiating interests within global politics.

\section{Technology as a Factor Shaping Transatlantic Dynamics}

Historically, technological preeminence was held by major West-European nations - Great Britain, France, Germany. Europeans were efficient in adapting solutions based on developments in technology and mathematic made by Arabs, Indian and Chinese thinkers to foster societal change. Around the $14^{\text {th }}$ century Europe surpassed other regions in technology with major improvements in shipbuilding, navigation, weaponry and printing. A particular combination of factors, providing different types of opportunities enabled the rise of Europe as a global power. They ranged from overseas expansion and conquest to state systems that were more capable of embracing innovation and industrialization. The development of technology, contributing to the evolution of the economic and social structures, has proven to be an integrating power through history. The Industrial Revolution that originated in Great Britain in the late $18^{\text {th }}$ century tied the world together more intensely than ever through the introduction of technology that stimulated flows of capital and people. The railroad, telegraph and steamship enabled the introduction of modern methods of mass production and distribution. The automobile, radio and airplane that took mass imagination in the $20^{\text {th }}$ century marked the life-style and promised even greater opportunities for future development.

From the beginning of the Industrial Revolution until the Cold War era, Europe was to shape global history. Its position in the global affairs started to decline at the beginning of the $20^{\text {th }}$ century, and when World War II was over it was evident that the United States gained the status of global power. The primacy in the global affairs has been passed to the nation that had its roots in the European civilization, which created a sense of affinity enabling a long-term transatlantic alliance. The idea of "the West" has become one of the most influential in the history of the past century.

Americans, whose worldviews have been rooted in European culture and strategies oriented at social and economic developments, easily embraced technology and engineering as a major part of their national identity, constructed from the beginning of the nationhood. During the revolutionary era, military necessity and political needs made technological change indispensable. The settlement of the vast North American continental landmass that followed during the nineteenth century, the need for transportation, railroad project, spawned development of powerful technologies. The United States has become the global center of revolutionist inventions, that inspired the Europeans, and has been a point of envy. As Robert Middlekauff puts it "increase in business and populations did not amaze Americans who had long had great expectations from themselves. To the heirs of people who had begun by thinking of themselves as settling the New World in the service of God, success - increase and growth in the things of this world - seemed only their just deserts, only their due, and a part of the eternal order of things" (Middlekauff). On the other hand, "the machine question" has been used in the art and social debate 
to distinguish the European spirit from the American one. Technology and science have been integrally related to an evolving of the American identity and self-definition. The age of steam train expansion added technology to the elements of the American foundational myth.

Technologies of transport became vehicles for the conscious creation of foundational myths through civil religion. The rhetoric of national progress was significant as public, private and political interests blended. America may well have hosted unprecedented technological enthusiasm and initiative for most of the nineteenth century very much of the conviction that technological progress was the best, or only, way, for the newly independent nation to prosper in the world and the way, that the United States had to follow at any cost (Dalsgaard).

In the period of dynamic technological development, American intellectuals were convinced that a specifically American culture could be built upon the machine. Urbanization, reconstruction, industrialization have become distinctive points in defining the American cultural self. Before the beginning of the $20^{\text {th }}$ century, American art and culture were highly influenced by European trends and the old continent represented the epicenter of all things artistic. The new era of economic development resulted also in undertaking new forms of artistic and social expression, considered unique for Americans. The French sociologist Andre Siegfried observed in a popular book of 1927, America Comes of Age: "The American people are now creating on a vast scale an entirely original social structure which bears only a superficial resemblance to the European. It may even be a new age" (Surette). Marcel Duchamp famously claimed that the machine was the greatest American contribution to the twentieth century. Accordingly the 1927 "Machine Age" New York exhibition collected works that provide an insight into American fascination of the of the manmade environment: majestic skyscrapers challenging old records of height; light, airy suspension bridges ringing new urban landscapes. "There is a great new race of men in America, the engineer, who 'has created a new mechanical world" " proclaimed the show's organizer, Jane Heap (1925). The idea of the machine age served as one of the tools of the transformation from a predominantly rural, Protestant society to an urban, modern world of automobiles, radios and electric toasters. But most of all the concept provided a lens through which the society focused its self-image, connected to the achievements of technology and science. Furthermore, technology and industrialization brought the admiration of the Europeans, and consequently -the rest of all the world.

At the beginning of the $20^{\text {th }}$ century wealth started to underlie America's sense of itself as a special country. Economic and industrial achievements joined by the sense of political leadership, allowed the United States to take the superpower role on the global scene after World War II. At the time technology and science already belonged to the notion of American exceptionalism, in the sense that the United States departed from the established way of doing things, creating new, important qualities in social life and the economy. This interpretation is especially interesting in the context of transatlantic competitive relations, as before America entered the world scene, the established way of doing things had always been defined by Europe. The conviction that America is better than other economies and Americans are 
the nation pushing the boundaries of human achievement forward spread on the base on a range of variables, from economic freedom to the ability to wisely use resources and support innovation. But European connections were not without meaning. Interestingly, while answering the question "Why American is so reach?" The Economist puts the great scientific exodus during WWII as one of the three main reasons, apart of the common law and massive immigration: "There is no fundamental reason why the US should be the center of the scientific world but for a time it was the only place in the world safe for many scientists" (Smith). The inflow of technologies from abroad played a major role in US industrial development, particularly in the late $19^{\text {th }}$ century. Technology has often flowed to the United States in the form of immigrant scientific and engineering talent and through foreign investment. During America's early industrialization, immigrant engineer-entrepreneurs were crucial for technology and enterprise development. The largest wave of scientific immigration came in the 30. Many scholars left Europe because their life was in danger, as in the case of Jews and they were restricted in their research. Over 20 of Germany's 55 Nobel Laureates of the time fled the country, and the majority of them relocated to England or the United States (Fleming and Bailyn). The Second World War transformed the US into a global power, and the intellectual potential that cumulated in the war period, enabled and facilitated many of the most important technological and economic processes of the time - from winning the war to fueling the post war economic boom. Striving for primacy in the technological race, Americans enabled the exodus of Third Reich scientific and engineering personnel, who became valuable assets in the new geopolitical circumstances ${ }^{3}$. By 1955, more than 760 German scientists had been granted citizenship in the US and given prominent positions in the American scientific community. Many had been longtime members of the Nazi party and the Gestapo conducted experiments on humans at concentration camps, used slave labor, and committed other war crimes. Their work substantially influenced the Cold War missile and space race, providing the US with cutting-edge technologies. The list of the most prominent scientists and engineers within this group includes: Hans Ohain - inventor of the jet engine, Werner von Braun who lead early NASA projects, Herbert A. Wagner who developed a radar-guided aircraft system or Hubertus Strughold, who played an important role in space medicine. GermanAmericans were key contributors in leading the American postwar economy to its historic peaks (Rhodes). The US policy towards Nazi scientists was not a subject of a diplomatic disputes at the time, but remains a controversy for the American and Europeans societies. The American and international public was shocked to learn that that US military Intelligence "cleansed" the files of Nazi references and allowed them US citizenship and protected them from investigation (Feigin). The operation was treated as part of the Cold War race between the Soviet and American rocket and other technological programs, proving that technological advance was seen

3 Because of concerns over providing an orderly process and legal cover for the importation of further specialists to help in the Pacific War, the US Joint Chiefs of Staff created a secret Operation Overcast in July for the short-term exploitation of 350 experts. When hostilities ended shortly thereafter, however, the program continued, because the US armed services wanted the benefit of German knowledge. Project Paperclip, the US operation which enabled more than 700 scientists spirited out of Germany. 
as a major tool in the geopolitical struggle. National strategy priorities prevailed over ethical concerns in major European states and the British and French governments also developed their own programs based on ex-Nazi specialist manpower (Neufeld).

Prevailing philosophies and ideologies of the western societies created as much a platform for cooperation, as for competition, but ultimately lead both societies to the privileged status. The transatlantic market has been built on the common attitudes toward trade and development and trust secured by common cultural values. In consequence, European investments often served as a main stimulus in the course of economic build-up of America $19^{\text {th }}$ century infrastructure projects - steel mills and railroads, while the United States, helped Europe recover from War World II devastations. The debate about terms and requirements of the Marshall Plan between 1947 and 1950 determined the shape and fate of Europe for half a century. In effect, the United States disbursed USD 13 billion over the four years 1948-1952, equivalent to around USD 88 billion today (The Economist). The recovery plan proved to be revolutionary in its economic outcomes, but also in its design that it required mutual cooperation among 16 countries (a $17^{\text {th }}$, the German Federal Republic, joined in 1949).

The attitude of generating multilateral solutions to common problems, turned out to be a push in European integration. The concept of "Politics of productivity," proposed by Charles Maier was introduced as an explanatory framework for the American policy towards Western European countries after World War II (Maier). Apart of the economic context, politics of productivity has been perceived to as a tool to depoliticize social and economic issues, enabling Western European societies to overcome social conflicts resulting from scarcity. Americans perceived their socio-economic history in this respect as a pattern to follow. It was agreed that improvements in industrial performance and productivity presented a major challenge in rebuilding Europe's post war economic structures (Mathias and Davis; Tann). Of no less importance was the strategic purpose of fortifying a "free world" united by common ideals - those embodied by the American culture rooted in European legacy - and weakening its enemies (Boel).

An important component of the Marshall Plan was the technological assistance offered by American agencies directed at increasing productive efficiency and labor productivity in Western European industry. In result, consultancy and technical assistance "reached almost every plant in every industry, marketing agency, and agricultural entity in Western Europe, introducing them to a technology more than a generation in advance of what they were using" (Silberman).

Transatlantic partners were also trying to narrow the technological gap between Europe and America, by sharing the most advanced practices and technologies already developed in the United States through the Marshall Plan's Technical Assistance Programs. This process illustrates how the transfer of modern technology contributed to the rise of the United States as a global political and economic power.

A vivid example of the multilevel connections that were established at the time, represent the computing industry involvement in knowledge and technology training. Computers at the time symbolized a primacy of the American technological tough, which revealed the role of technology as a tool of Americanization. Not only were the American production and management techniques and know-how transferred to Europe at the time, but also the economic model and the entrepreneurial 
spirit. As Deputy Director Fitzgerald of the Mutual Security Agency (MSA) put it in 1952: "what we are basically trying to do (...) is to change attitudes of mind and thinking of 250 million people" thereby overcoming all "restrictive business practices" impeding economic growth in Western Europe (Boel).

During the Cold War, scientific and technical training became a crucial strategy for waging politics at regional and global scales. Politicians on both sides of the Iron Curtain strongly believed in the power of technology to win ideological battles between the East and the West, which is best illustrated by US government's reaction to the USRR's space program. On October 4, 1957, the Soviet Union beat the United States in the launch of the first satellite to orbit Earth, which was a major catalyst for space and other innovative directions programs. The "Sputnik shock" rough a conclusion on a failure of American science and engineering: the launching of the world's first artificial satellite demonstrated that the Soviet Union had first achieved impressive economic results with highly dangerous consequences. In response, science rose to prominence with massive government funding of university-based research and efforts to meet the education and science challenge.

Inventions and techno scientific practices were used as pivotal mechanisms to mediate power relations during and after the Cold War. These changes affected not just the arms race and the space race but also research in agriculture, biomedicine, computer science, ecology, meteorology, and other fields. Specific conditions of the Cold War influenced transatlantic relations, firming up the security alliance, intensifying the distribution of knowledge, as well as enabling many strategic joint initiatives. The years from 1945 until the early 1970s were exceptional in the history of transatlantic relations over the long $20^{\text {th }}$ century.

In the years after 1945, American military personnel, businessmen, Marshall Plan administrators, labor leaders, foundation officials, and educators moved out across Western Europe to spread the gospel of democratic capitalism and anti-communism. They encouraged Europeans to adopt the "politics of productivity," to open their markets, integrate their economies, and allow Hollywood films, jazz, and rock ' $n$ ' roll to circulate freely. "You can be like us" was the American promise - one which many perceived as a threat (Logemann and Nolan).

\section{Pillars of Cooperation/Points of Disagreement}

Transatlantic postwar policies set the foundation for a several decades of cooperation based on trust and common interest perception, that went beyond the Cold War context. In effect, the long lists of the political objections important for stabilizing the international structure, has been secured: the Soviet Union was contained, and eventually won over, West Germany, and later Easter European countries were integrated into Europe, the Atlantic military alliance has proven to be effective and durable and Europe remains peaceful and prosperous. These historical accomplishments did not, however, come without effort and transatlantic cooperation creates a defining frame to sustain them. The cooperation in Science and Technology between the European Union and the United States gained an institutional dimension in 1998 in the form of S\&T Cooperation Agreement. The agreement was renewed four times and extended in order to adapt to the changing international challenges. It is not a form 
of a replacement of the extensive bilateral cooperation between individual Member States and the US, but rather provides a complementary dimension. Partners see that cooperation in research, innovation and new emerging technologies has strong drivers for increased trade and future economic growth (Herlitschka). There are currently four priority areas of the joint efforts:

- Marine and Arctic Research

Cooperation aims at increasing the understanding of climate change in the Arctic region and its impact on socio-economic activities such as marine transportation and tourism, fisheries and aquaculture, and oil and gas extraction. The objective of the research is to improve the predictability related to the changes of the Arctic eco-system.

- Research infrastructures

A number of collaborative initiatives have been ongoing joining European and American leading research institutions. The list includes research conducted in the frame of the CERN LHC or the dialogues set up in the Environmental and Earth Sciences domain where Research Infrastructures play a role in supporting the Transatlantic Ocean Research Alliance.

- Health research

The US is the EU's leading partner when it comes to health research either in terms of the numbers of US participations in the Framework Program (both FP7 \& Horizon 2020) projects. The US National Institutes of Health (NIH) plays a crucial role as a facilitator, but also the National Science Foundation (NSF) and other important players from the nongovernmental sphere, as the Bill and Melinda Gates Foundation, are also involved.

- Transportation Research

Cooperation is structured mainly between the European Conference of Transport Research Institutes (ECTRI) and the Transportation Research Board of the National Academies (US-TRB). Partners work together to address global societal challenges connected to transportation (Roadmap for EU - USA...).

The formalized S\&T framework also contains specific area agreements apart from the S\&T Cooperation Agreement. EU-US scientific cooperation takes place under the auspices of the Joint Consultative Group, the EU-US Space Dialogue, the Transatlantic Ocean Research Alliance, the Energy Council and the Transatlantic Economic Council.

The initiatives listed above are part of the efforts towards the development of more knowledge-intensive economies in which research, its commercial exploitation, and other intellectual work are of growing importance.

It is worth noticing that in the United States, industry funds about $62 \%$ of all R\&D projects. The EU average is $54 \%$, but with considerable range (e.g. nearly $70 \%$ for Germany compared to $45 \%$ for the UK) (Acheson and León). The R\&D expenditures structure demonstrates a clear shift toward markets reflecting the long established trend of creating incentives for joint public-private R\&D initiatives. But in the United States as well as in Europe, governments still play an important role in setting the direction and providing financial grounds for national innovation systems, as most public funding for research is administered centrally. The position of the state in building the S\&T framework is clearly illustrated by the capabilities of the US agencies, such as the US National Science Foundation (NSF), the US National 
Institutes of Health (NIH), the US Department of Energy (DoE) and the US Department of Defense (DoD), that fund basic research. In Europe, the overwhelming majority of funding is at the country level, distributed by national governments. It is worth mentioning that the institutional S\&T framework is one of the many already developed on both sides with multiple partners. The scopes of cooperation may be set in an ambitious way, but the policies on the both sides do not stress priority for the other side of the transatlantic link. The strategic European framework for international cooperation in science and technology (S\&T) contains a wide numbers of agreements with every important economic actor on the globe. This is a part of a wide internationalization policy, that is grounded in an open innovation system, but has not become a tool of the transatlantic strategy. Policies of the EU are inspired by the need to strengthen Europe's position vis-a-vis non-European countries, in particular the technologically leading countries such as the US and Japan, which have been considered as threats. On the other hand, the United States does not show any signs of using its long established partnership with Europe to strengthen its leading knowledge economy position, which is being increasingly threatened by China. There is no doubt that transatlantic cooperation in terms of research is well developed: bilateral US-EU flows in research and development are the most intense between any two international partners but this fact is not a part of a more complex strategy, reaching behind current economic needs (Fikkers and Horvat). Both sides of the dialogue declare that expanding the cooperation lies within the sphere of their strategic interests, but at the same time differences are widening the European and American shores of the Atlantic Ocean. Although traditionally the US and Europe have worked closely together on issues of stability and wealth, the developments in the area of S\&T are not reflecting the growing importance paid to innovation policies on both sides of the Atlantic. A cooperative innovation system requires a high-level of mutual trust amongst partners, but trust in transatlantic relations has been seriously eroded. The technological dimension has had one of the most serious strains in the recent periods as well. The obvious example here would be the surveillance scandal born of activities of the US National Security Agency (NSA) that have led to widespread assertions that trust has been eroded within the transatlantic relationship (The Guardian). The documentation revealed by Edward Snowden, a former contractor working for the US National Security Agency (NSA), published in The Guardian and The Washington Post on June 6, 2013, proved that the NSA is used by the US authorities, which are accessing and processing the personal data of EU citizens on a large scale via, among others, the NSA's warrantless wiretapping of cable-bound internet traffic (UPSTREAM) and direct access to the personal data stored on the servers of US-based private companies such as: Microsoft, Yahoo, Google, Apple, Facebook and Skype. Such activities were carried out under the NSA's program Planning Tool for Resource Integration, Synchronization, and Management (PRISM). The controversy surrounding the NSA's espionage activities exposed differences not only in diplomatic means considered legitimate in the United States and EU but resulted in a breach of trust that influences future cooperation within the sphere of transatlantic cyber and technology partnership. This case is important because it illustrates how the transatlantic world is divided in terms of use of the most important technology of the modern time (Stevens). The right to informational self-determination is interpreted differently, the question of balance 
between cyber security and data protection does not have a common answer, just as the one regarding the governing model of cyberspace (The White House, International Strategy...; Fontaine and Rogers; Maurer). These are issues connected to the normative foundation and regulatory principles of internet technology usage and they are critical if the United States and the European nations are willing to still stand on a common ground.

Internet governance is one of a number of issues with a global dimension on which the United States and Europe are at odds, but as global leading powers they can't ignore them. They also can't ignore the fact that technology helps achieving political goals and faces the growing challenges of the contemporary world. This is especially true when it comes to the great emerging threats - energy and climate change, urbanization, resource scarcity, and aging societies, to name a few - all of which demand scientific cooperation and the effective integration of scientific perspectives into policymaking processes. Global competitiveness is still the major framework here. In the second decade of the 21th century for the first time since the end of World War II, US global leadership in innovation is being brought into question. The superficial overlook of global economic affairs may lead to the conclusion that innovation is the strength of the West and that what gets developed in the West is modified and transferred to other regions of the world. But the reality of recent years does not support this assumption. The rise of China and India have already put these states high in the international hierarchy, not only as economic but also, political powers. The economy inevitably influences the ability to act, and the economic potential of these two examples is not limited to their industrial base. One of the important elements of China's strategy is stimulating investments in high technology industries, so the country is increasingly becoming an important centre of technology development. This is certainly the most serious challenge for the Western economic leaders to meet. Within the next decades, the economic growth of China, India and other from the tier of the "new powers" like Brazil or Indonesia is likely to bring about a structural shift in the global economy and the balance of power.

Cooperation on trade, innovations and technological developments could have been a counterbalance for the shifting positions of the West, but for the time being differences outweigh the common grounds. Many of them were highlighted during the discussions accompanying the Transatlantic Trade and Investment Partnership (TTIP) negotiations. The idea of the common agreement has lost momentum with the new trade strategies introduced by Donald Trump's administration and the heated public debate in the US and the EU countries. What could have been the largest trade agreement in history, for now remains a symbolic illustration of the transatlantic strains. The privileged status of the transatlantic economy is increasingly seen at risk, but the alliance has not yet entered the phase of mobilization. Common strategies are more visible in the sphere of political rituals, than realities. Neither the United States, not the European Union are strongly oriented at redefining the alliance in order to create new opportunities to influence the global economy. 


\section{NATO as a Technological Alliance}

The North Atlantic Treaty Organization remains the most stable base for transatlantic cooperation and the most visible demonstration of the alliance. As such, it has a great transformative power, not only with regards to the institutional, but also technological level of security realities. The Alliance has been able to keep its technological edge over adversaries for nearly seven decades years because of the innovative capacity of its transatlantic members. During this time, the United States and Western European countries have been the most technologically advanced industrialized nations able to accumulate and exercise their military powers in order to establish their role in the international hierarchy.

Advances in military technology have long influenced the course of international politics. Military inventions, such as the atomic bomb or rocket-propelled missiles changed the course of history, demonstrating the power and potential of the nation that poses them. Defense innovations played an important role in United States global policies, especially in the context of NATO cooperation. For over 50 years the Pentagon Defense Advanced Research Projects Agency (DARPA) had been responsible for producing an unparalleled number of major innovations, from the internet, through RISC computing to global positioning or micro-electro-mechanical systems (MEMS).

In its recent history, NATO has undergone a number of fundamental changes, rooted in the revolution in military affairs, aimed at an adjustment to the modern technologies, as well as to the new paradigms of war and security. This idea originated in the concept of the Military Revolution (MR) proposed by historian Michael Roberts in the 1950s to describe critical changes in the strategy, tactics and sociopolitical institution in early modern Europe. Computers and other groundbreaking innovations brought a major transformation in nearly every corner of the industrialized societies, becoming the later phase of the revolution in military affairs. The US military initiated the earliest research into electronic digital computers and the Pentagon was the largest customer of computer companies until about the 1970s. In the 1990s, efforts were concentrated on using the potential offered by advances in information technology (IT) to revolutionize the conduct of warfare. The communication technology revolution, whose main elements have been the personal computer, lightning-fast global telecommunications and the Internet, developed in the framework of the defense research projects marked this stage of transformations. Such dynamically progressing advances created a technology gap that had long been the major conflicting factor in transatlantic military relations. In the middle of the $20^{\text {th }}$ century Europe was already behind with its developments. In the 1960s, the US was spending one-third of its much larger defense budget on military R\&D compared with a quarter of a smaller budget in Europe, which illustrates the growing differences in technology capabilities (Dunne and Braddon). In consequence, the importance of 'burden-sharing' issues in terms of cold war NATO operations has been continually increasing.

Transatlantic partners have been long at the forefront of military technology development, facing, at the same time, serious strains eroded in the different views on the importance and shape of the military capabilities. Military transformation is the key word in NATO present agenda, often in reference to the concerns about the shortfall between European capabilities and European political and military roles. 
While the United States spends over 3 percent of its GDP on defense, NATO Europe spends only about 2 percent (NATO Defense Spending). Furthermore, only Norway, Turkey and the United Kingdom are dedicating the same proportion of their defense budgets on research, development and procurement as does the United States. Historically, the Europeans have invested much less than the Americans in military $R \& D$, and the European efforts have for the most part been scattered and dispersed in numerous national programs.

This disproportion of power and possibilities makes the NATO structure unbalanced, but its roots are not merely political, but foremost strategic. The United States has long been preparing forces for a transoceanic power projection which needed a robust arsenal as well as serious investments in mobility. The major NATO scenario of the confrontation of enemies during the Cold War has been a massive attack from the East through the central plains of Germany. Preparing for a major battle in Europe precisely required the capacities most of its European Allies did not need: mobility, sustainability, the capacity to project and sustain forces over distance and time.

As highlighted by James Appathurai in "NATO Review," today's political and strategic situation is much more complex, in comparison to the period of the alliance's beginnings:

At the practical level, NATO forces are working together in robust, complex and difficult missions, but the US lead in military technology makes working together difficult for deployed forces. At the political level, the desire among Allies to work together is hamstrung by the growing complexity of doing so. At the strategic level, a growing transatlantic divergence in capabilities can perpetuate both legitimate grievances and unfair stereotypes over burden-sharing and influence (Appathurai).

The imbalance in European and US military capabilities is an obvious issue influencing common relations of the NATO members. The US perspective focuses on concerns that this imbalance could grow to such an extent that US and European armed forces will find it increasingly difficult to operate effectively together. In such a perspective, the technology gap illustrates contradictory strategies between the United States and Europe, generates domestic burden-sharing accusations, and effects in the United States' more unilateralist foreign and security strategies (Barrios and Koepf). On the other hand, taking more responsibility for their own security and defense seems inevitable for the member states of the European Union and security indeed has become the new front line of the European project (Barrios and Koepf). Global Strategy for the European Union's Foreign and Security Policy adopted in June 2016, apart from defining the current role and ambitions of the European Union in the security domain, also provides tools to meet the designed goals (Lehne). The European Defense Action Plan comprises a European Defense Fund and other actions to help states concentrate on research development and foster a competitive and innovative defense industrial base - amongst them a groundbreaking plan to earmark EUR 500 million per year to spend on R\&D4. Planned areas of cooperation

4 Planned research is to be concentrated on unmanned aircraft systems (RPAS), mobile reconnaissance robots for urban warfare (SPIDER), and autonomous monitoring platforms. 
include operational cooperation, defense industry and research and security capacity-building. Paradoxically, this long needed strategic shift is brought about by the crisis in transatlantic relations. As stated in the European Commission's document:

(...) the transatlantic relationship is evolving. The onus of improving European security lies first of all in European hands. The resources should be there: collectively European countries are the second largest military spender worldwide. Together with the United States and others, Europe has a responsibility for global peace and security. While acting together with our partners will remain the EU's norm and preference, we should be able to act alone when necessary (Reflection Paper... ).

American key leadership has been expecting such a point of view to be expressed but the question whether they can fulfill the gaps still remains open.

The picture of the future challenges in the area of transatlantic military technological cooperation wouldn't be complete without the risks posed by dynamically progressing privatization and the internationalization of military production. It is beyond any doubt that private military companies along with private civilian companies have been at the forefront of the current phase of the technological revolution in military affairs (RMA). Though the US Department of Defense or European government bodies were the original costumers and initiators for innovative projects, the advances in research have played a central role in creating a host of major global discoveries and industries. Historically in all Western economies, military R\&D has had a positive impact on the economy and civilian production, through the 'spin-off' - transfer of technology to the commercial sector. Today, the relations between civilian and military technology are likely to take an opposite course: innovation is more concentrated in the private sector, where more commercial technologies than ever before have military applications.

The shift in focus towards 'spin-in' from civil to military sectors is fundamentally transforming the military R\&D process and the defense industry itself. As P. Reuckner noted already in 2000: "the trendsetters of electronic development are in the civil market where ever shorter innovation cycles are setting the pace: the two companies Intel and Microsoft alone allocate higher R\&D funds than DARPA, responsible for applied defense projects in the Pentagon" (Ruecker).

As assessed by the study from New York University examining the US National Security Technology Accelerator: "The emergence of international commercial and consumer high-tech markets has substantially displaced DoD (US Department of Defense) as the center of gravity for global research and development. While through the mid-1980s, the US government accounted for nearly 50 cents of every research dollar globally, today the amount is less than one-tenth of that" (National Security Technology Accelerator...).

Analysts have long been talking about privatization and the internationalization of military production, as a factor influencing international security and economy spheres. The defense industrial complex restructuring following the end of the Cold War has left world arms production highly concentrated. This process is strictly connected with transformations across military production base in the Western countries and the growing role of high-tech systems and components in the defense capabilities. The evolution of the military market in the United States provides the most 
striking example: concentration of the arms industry lead to limiting the number of companies from 20 to 4 in 1998. Even further concentration was planned, but has been blocked by anti-trust concerns (Skoens and Weidacher). In result, strategic industries are increasingly shifting from the government's influence - a process that causes important security dilemmas. Private military companies have to face the realities of the shrinking defense budgets, which leads the industry to turn the focus of its sales efforts abroad. International mergers of defense companies were seen as an instrument to keep their existence and profitability. But the process has an essential strategic side-effect: highly sophisticated weaponry is widely internationally distributed, in some cases leading to the relaxation of arms export restrictions and transforming the national security spheres of the involved countries. A growing number of emerging or unstable states have been investing in developing indigenous defense industries.

With the changes in technology, it is becoming impossible for countries to maintain the capability to produce a comprehensive range of weapons independently, so companies shifted their policies to partnerships and technical alliances with foreign suppliers. The globalization of defense industries resulted in the greater impact of multinational corporations, technology supply chains that span the globe, joint development and manufacturing agreements, and the outsourcing of defense technology production (Bitzinger). All these have processes shaped the arms industries in a much more commercial way than before with competitive tendering, contracts awarded with reference to market prices, at the same time the ability of the states to control this sphere of strategic importance is diminishing.

The multi-role strike-fighter program (JSF) - the largest acquisition program in history, worth USD 300 billion, clearly illustrates this dilemma (Joint Strike Fighter Program official website; Gertler). The project is aimed at developing a new model of cooperation in producing highly sophisticated weapons. Joint international research and development cooperation is based on the assumption that participating partner nations not only attain interoperability but experience savings due to costsharing. The JSF co-development program includes: the United Kingdom, Italy, the Netherlands, Canada, Norway, Denmark, Australia and Turkey (Joint Strike Fighter Program official website). Such a wide scale of cooperation in strategic areas inevitably raises questions about United States military's technological edge and how such a process may affect national security of the involved parties in the long term. Most of the involved countries have been long trusted allies, but just as similar forms of military production have become more common, the strategic risk embedded in them, has increased. The proliferation of defense technologies clearly has the potential to diminish the Western margin of military superiority ${ }^{5}$. Internationalization of the defense industrial complex connected with military know-how proliferation also benefits countries that are questioning the Western position on the international arena, such as China. Data released in March 2015 by the Stockholm International Peace Research Institute (SIPRI) placed China as the third largest arms exporter

\footnotetext{
5 The nature of this concern is clearly demonstrated by so called "boomerang effect" when advanced weapons and arms making technology fall into hands of adversaries, as happened in the case of Stinger rockets MANPADS (Man-portable air defense systems) supplied to Afgans in the 1980s to fight the Soviet Union, that become diverted to terrorists.
} 
in the world based on the 2010-2014 sales period (Wezeman). In 2016, SIPRI stated, that: "Chinese exports of major arms increased by 74 per cent between 2007-11 and 2012-16, and China's share of global arms exports rose from 3.8 to 6.2 per cent" (Fleurant et al.).

In light of the transformation of the global innovation environment, NATO's technological primacy is becoming even more relevant for the status of the alliance and as a factor of the global stability strategy. The defense-capabilities gap that divides the United States from its European allies is influencing common relations to a significant extent, creating a challenging environment for transatlantic cooperation. The ability to create a balanced and trusted cooperation environment is crucial in addressing growing challenges: the decline in the United States' and its allies' share of global military spending; the rise of spending in Asia, the Middle East, and Russia; and the potential strategic trajectories of both (Ablett and Erdmann).

\section{Conclusion}

Innovation and technology are related concepts that have been at the core of the worldwide economic evolution. Globalization combined with progress in science and innovation brought new meaning to technological advancement. Today it is considered to be one of the instruments of state power, measured in R\&D funds, innovation supporting policies and patent rights. True economic leadership comes only with the ability to produce high-quality high-technology goods and services and to create new and innovative products and technologies. Surprisingly though, the integrative effect of globalization falls short with regards to transatlantic cooperation in general and in the sphere of technology. After the end of the Cold War, US and Europe played the most important role in the global technological competition, but surprisingly they have never made science and technology a component of the common transatlantic strategy. The ability to produce a high-end invention, still provides a competitive advantage on the global market, on which the position of the partners is increasingly threatened by a growing influence of Asian economic powers. The economic interface between Europe and the United States compel both sides to deepen science and technology cooperation, however there have been no systematic efforts to turn this framework into a strategic one.

Efficient innovation infrastructure and high human potential, market power and technological edge, may have resulted in further developments that enhance the international influence of the transatlantic partners. Taking a comprehensive look at the innovative capacity of the United States and European countries leads to conclusion that this does not seem to be the case of the last decades of their relationship. Even the fact China is increasingly targeting advanced industries for domination, has not provided enough mobilization for staging a new era of technological cooperation.

Cooperation within the field of science and innovation is also an important factor in meeting challenges of the future. As outlined in the US National Intelligence Council's report Global Trends 2030, the nexus of food, water, energy, and other resources, in connection with climate change, is likely to have a broad global impact. The report indicated the growing demand for food, water, and energy, in 
connection with the rising middle class, urbanization, and climate change, as one of five "mega-trends" shaping the world out to 2030. Technological innovation was termed a "game changer," which will interact with "mega-trends" to determine the type of world that will emerge in the next several decades (Global Trends 2030...). This provokes the question of leadership in governance of these global issues and the future role of the United State and Europe within this field. Problems related to climate, the growing consumption of energy, shrinking strategic resources need technological solutions. Some of them, however, may require an even deeper level of governance cooperation from the part of the developed states. Technological innovations related to the accumulation and use of data, advanced manufacturing, resources, and health will probably transform economic, political, and military activities around the world. In addition, technological innovations, especially related to the accumulation and use of data will shape the society in the coming decades. Environment and climate issues make an exception within this sphere, but generally little attention is paid to advance to the Science and Technology content of issues on the US-European political agenda. In consequence, these activities are, to a growing extent, transferred from the area of responsibility of the states to the private and corporate sphere. Companies, especially transnational corporations, are aware of the fact that now, more than ever before, discovery and knowledge can enhance their competitiveness. There are ready to invest their resources in the kinds of science that are commercially promising. Generally the potential contribution of US-European scientific cooperation to transatlantic relations is overlooked, while it could be a mobilizing factor, bringing both parties together. The alliance built its leverage during the Cold War period, and the competitive environment of global politics at that time were helpful in defining common spheres of interests and values. In the century that was announced as 'technocratic,' 'post-industrial' or 'knowledge-based,' partners on the transatlantic arena seem to be turning in the direction of more traditional economic and social solutions instead of projecting the technology-driven renaissance based on the synergy of their potentials.

\section{References:}

Ablett, Jonathan, Erdmann, Andrew. "Follow the Money: Strategy, Scenarios, and the Global Shift in Defense Power." McKinsey on Government. No 8, Spring 2013 (Special Issue: Defense): 28-43.

Acheson, Helena, León, Gonzalo. Evaluation of the EU-US Agreement on SET, 2013. Web. October 3, 2017.

Appathurai, James. “Closing the Capabilities Gap.” NATO Review. No. 3, 2002. Web. October 11, 2017.

Barrios, Cristina, Koepf, Tobias. Re-mapping the Sahel: Transnational Security Challenges and International Responses. EUISS Report No. 19, EU Institute for Security Studies, Paris 2014. Web. October 6, 2017.

BILAT USA 2.0. Recommendations to Expand Participation of EU and US Businesses in Collaborative Transatlantic Research, Technology, Development and Innovation (RTDI) Projects. Web. October 15, 2017.

Bitzinger, Richard A. "The Globalization of the Arms Industry: The Next Proliferation Challenge." International Security. Vol. 19, No. 2, 1994, https:/ / doi.org/10.2307/2539199. 
Boel, Bent. The European Productivity Agency and Transatlantic Relations, 1953-1961. Copenhagen: Museum Tusculanum Press, University of Copenhagen, 2003. Web. October 11, 2017.

Dalsgaard, Inger H. "Making Myths about the "Merrikins". Imagining American Ingenuity in the Jacksonan Era." [in:] Heusser, Martin, Grabher, Gudrun (ed.). American Foundational Myths. Tübingen: Gunter Narr Verlag, 2002: 42-64.

Dunne, Paul J., Braddon, Derek. Economic Impact of Military RED, Bristol: University of the West of England, June 2008. Web. October 1, 2017.

Feigin, Judy. The Office of Special Investigations: Striving for Accountability in the Aftermath of the Holocaust, December 2006. Web. October 12, 2017.

Fikkers, Derek Jan, Horvat, Manfred (ed.). Basic Principles for Effective International Science, Technology and Innovations Agreements. European Commission, 2014, https://doi.org/10. $2777 / 11479$.

Fleurant, Aude, Wezeman, Pieter. D, Wezeman, Siemon T., Tian, Nan. Trends in International Arms Transfers 2016. SIPRI 2016. Web. October 7, 2017.

Fleming, Donald, Bailyn, Bernard (ed.). The Intellectual Migration: Europe and America, 19301960. Cambridge MA: The Belknap Press 1998.

Fontaine, Richard, Rogers, Will. Internet Freedom. A Foreign Policy Imperative in the Digital Age. Washington, DC: Center for a New American Security, June 2011. Web. October 13, 2017.

Foreign Direct Investments in the United States. 2016 Report. Washington: Organization for International Investment, 2016. Web. December 12, 2016.

Gertler, Jeremiah. F-35 Joint Strike Fighter (JSF) Program: Background and Issues for Congress. Library of Congress Washington DC Congressional Research Service, 2014. Web. October 16, 2017.

Global Trends 2030: Alternative Worlds. The National Intelligence Council, 2012. Web. December 11, 2016.

Heap, Jeane. "Machine-Age Exposition.” The Little Review, Spring 1925. Web. October 11, 2016.

Herlitschka, Sabine E. Transatlantic Science and Technology: Opportunities for Real Cooperation Between Europe and the United States. New York: Springer, 2013, https://doi.org/ 10.1007/978-1-4614-4385-8.

Heusser, Martin, Grabher, Gudrun (ed.). American Foundational Myths. Tübingen: Gunter Narr Verlag, 2002.

"Innovation in A\&D and a Call to Action." AED Corporate Innovation Digest. No 1, February 15, 2016. Web. October 11, 2017.

Jeremy, David J (ed.). The Transfer of International Technology. Europe, Japan and the USA in the Twentieth Century. Hampshire: Edward Elgar, 1992.

Lehne, Stefan. The EU Global Strategy, a Triumph of Hope over Experience. Carnegie Europe, June 4, 2016. Web. October 12, 2017.

Logemann Jan, Nolan, Mary (ed.). More Atlantic Crossings. Washington, D.C.: GHI, 2014. Web. October 16, 2017.

Maier, Charles S. "The Politics of Productivity: Foundations of American International Economic Policy after World War II." International Organization. Vol. 31, No. 4, 1977: 607-633.

Mathias Peter, Davis, John A. (eds.). Innovation and Technology in Europe - From the Eighteenth Century to the Present Day. Oxford: Oxford University Press, 1991.

Maurer, Tim. Cyber Norm Emergence at the United Nations. An Analysis of the UN's Activities Regarding Cyber-security. Cambridge, MA: Belfer Center for Science and International Affairs, September 2011. Web. October 14, 2017.

Middlekauff, Robert. The Glorious Cause: The American Revolution, 1763-1789. The Development of Manufacturing Technology in the United States. New York: Oxford University Press, 1982.

Neufeld, Michael J. "The Nazi Aerospace Exodus: Towards a Global, Transnational History." History and Technology. Vol. 28, No. 1, March 2012: 49-52, https://doi.org/10.1080/07341 512.2012.662338. 
National Security Technology Accelerator: A Plan for Civil-Military Industry Innovation. New York: New York University, 2015.

NATO Defense Spending. Web. December 2, 2016.

Reflection Paper on the Future of European Defense. European Commission, June 7, 2017. Web. November 2, 2017.

Roadmap for EU - USA SET Cooperation, European Commission, October 2016. Web. November 2, 2017.

Rhodes, Richard. The Making of the Atomic Bomb. New York: Simon and Schuster, 1986.

Ruecker, Paul. Electronics, Information and Communication Technology: Pacemakers for Defense. Systems Development, STN ATLAS Elektronik, 2000.

Silberman, James M., Weiss, Charles Jr. Restructuring for Productivity: The Technical Assistance Program of the Marshall Plan as a Precedent for the Former Soviet Union. Washington: Global Technology Management, Inc. 1992.

SIPRI. SIPRI Yearbook 1999. Oxford: Oxford University Press 1999.

SIPRI. SIPRI Yearbook 2014. Oxford: Oxford University Press 2015.

Smith, Karl. "Why is America so Great." Modeled Behaviour, November 8, 2010. Web. October 16, 2017.

Surette, Leon. Dreams of a Totalitarian Utopia: Literary Modernism and Politics. London: Ithaca 2011.

Stevens, Tim. "A Cyberwar of Ideas? Deterrence and Norms in Cyberspace." Contemporary Security Policy. Vol. 33, No. 1, 2012, https:/ / doi.org/10.1080/13523260.2012.659597.

“The Other Marshall Plan." The Economist. June 5, 1997. Web. November 2, 2017.

The Guardian, June 7, 2013. Web. November 5, 2017.

The White House, International Strategy for Cyberspace. Prosperity, Security, and Openness in a Networked World, Washington, DC, May 2011. Web. November 5, 2017.

Towards a European Global Strategy: Securing European Influence in a Changing World. European Global Strategy Report. IAI/PSIM/RIE/UI, Rome/Warsaw/Madrid/Stockholm 2013.

Veugelers, Reinhilde. "The Challenge of China's Rise as a Science and Technology Powerhouse." Bruegel Policy Contribution. No. 19, July 2017. 